Article

\title{
Sustainable Rural Development in Northern China: Caught in a Vice between Poverty, Urban Attractions, and Migration
}

\author{
Tianming Gao ${ }^{1}$, Anna Ivolga ${ }^{2}$ and Vasilii Erokhin ${ }^{1, *(1)}$ \\ 1 School of Economics and Management, Harbin Engineering University, Harbin 150001, China; \\ gtmmail@163.com \\ 2 Faculty of Social and Cultural Service and Tourism, Stavropol State Agrarian University, Stavropol 355017, \\ Russia; annya_iv@mail.ru \\ * Correspondence: basilic@list.ru; Tel.: +86-451-8791-7016
}

Received: 9 March 2018; Accepted: 6 May 2018; Published: 8 May 2018

\begin{abstract}
For a long time, the majority of China, which has the world's largest population, has been immobile and lived in rural areas. However, over recent decades, with the economic rise of China, rural labor has demonstrated a trend of moving to rapidly industrializing regions in search of higher income and better employment opportunities. Along with the labor cutback, out-migration introduces negatives to the sustainable development of rural areas, i.e., depopulation, the abandonment of rural settlements and agricultural lands, and the aging of the population, among others. Due to the threats of labor outflow to sustainability, studying the causes of China's rural out-migration can reveal lessons on how state policies can be designed to reduce the negative impacts of out-migration on rural communities. The purpose of this paper is to identify the major causes of migration movements among the rural areas of northern China that are considered to be the best-performing among the provinces of the country in terms of rural development, agricultural production, and the wealth of rural dwellers. A two-stage survey of a panel of experts involved: (1) respondents representing government officials and universities of the Heilongjiang, Jilin, and Liaoning provinces and the Inner Mongolia Autonomous Region, and (2) regional and district levels of administration, and research and public establishments of Heilongjiang Province. In stage three, drawing on the authors' own survey of 128 rural households in three counties of Heilongjiang Province, the major migration drivers have been identified, and the portfolio of a typical rural migrant has been developed. Some of the key findings are that migration intentions are fueled by the rural-urban income gap, poverty, a reduction of demand for labor in rural areas, underdeveloped infrastructure, the low quality of social services in rural settlements, and the low social standing of rural dwellers. The approach allows monitoring the dynamics of migration attitudes as responses to the policy interventions that are aimed at the sustainable development of rural areas.
\end{abstract}

Keywords: China; expert survey; migration; poverty; province questionnaire; rural area; sustainable development

\section{Introduction}

In the conditions of growing urbanization, many countries face the challenge of ensuring sustainable development alongside the social and economic progress of rural areas [1]. A critical bottleneck of the agricultural sector is that neither labor nor land can be easily replaced by capital. It is for this reason that in rural areas, sustainability is conditioned by land management and conservation, as well as by the retention of rural labor in the traditional habitats. In an ideal scenario, the rational 
utilization of natural, demographic, and economic resources that are aggregated in rural areas can potentially provide diversified development, full employment, and high living standards for rural people. However, the truth is rather different, as those countries with a prevalence of rural population and a high contribution of agriculture to gross domestic product (GDP) face the thorniest challenges in terms of sustainable rural development [2].

China has the world's largest population, of which the majority has always lived in the countryside. Traditionally, the Chinese rural population has been largely immobile, but over recent decades, rural-urban migration has taken place at a considerable scale [3], and Chinese rural migration has demonstrated a general pattern of rural labor moving from economically underdeveloped inland provinces to rapidly industrializing and urbanizing coastal regions in search of living and employment. Inter-provincial emigration and immigration levels have increased greatly with the economic development of China [4]. Over the previous three decades of economic growth, urbanization driven by globalization has spurred rural migration [5], while rural migrants moving to urban areas have provided flexible and cheap labor for China's industrialization [6].

There has been growing debate about whether the changing demographic composition due to rural labor migration could potentially threaten China's agricultural productivity and the development of rural areas [7]. Ye [8] emphasized a widespread view that industrialization undermines agriculture and hollows out rural communities. Indeed, between 1980-2018, rapid economic growth and urbanization in China caused a substantial shift in the structure of agricultural production and food consumption. Zhou [9] and Zhou et al. [10] attributed the growth in the consumption of food products of higher quality, nutrient value, and price in China (meat and meat products, milk and dairy products, and seafood) to the prejudice of cheaper and fewer nutrient crops. Consequently, Chinese meat and dairy producers demand more crops as fodder for agricultural animals, which increases the load on agricultural lands and accelerates their degradation [11]. In such conditions, China may soon run out of high-quality agricultural land resources that ensure sustainable food security in accordance with the four pillars of the Food and Agriculture Organization (FAO), i.e., availability, access, utilization, and the stability of food [11]. While the FAO considers food security as access by people to enough food on the domestic market by means of both domestic production and import, some Chinese experts [9,12-14] argue that the increasing scale of international trade threatens the food security of China. In contrast, Luan et al. [15], Ghose [16], and Zhang [17] treat food security as self-sufficiency when food availability is ensured predominantly by domestic production.

One of the principal solutions to contemporary challenges is the sustainable development of the territories that provide a supply of agricultural products and food [2]. Over the transition period of 1990-2009, there were certain reforms implemented regarding agricultural production and land relations in China. However, the globalized and urbanized world has brought the social and economic sustainability of rural areas into increasingly challenged surroundings $[18,19]$. In the case of China, rural areas lag behind urban ones in terms of living standards and quality of life, because of their low level of industrial development and urbanization [20]. Between 2000-2018, economic growth was generated primarily by urbanized southern and eastern coastal provinces [21,22]. In contrast, the predominantly rural northern parts of the country experienced rather modest economic growth since the first wave of reforms of the 1980s, when family farming was relaunched after decades of the total dominance of agricultural communes by centralized planning [23].

One of the core problems of China's rural areas is the structure of agricultural production [21]. The agricultural sector is dominated by small households [24], which provide the bulk of domestic product in agriculture. In China, the land area per capita is only 0.08 ha, which is far below the world average of 0.22 ha per capita [25]. As of 2016, the number of households is above 200 million, and the average size of a household is 0.66 ha (264 ha in the USA and 37 ha in the EU, respectively). China's land and water issues are the primary constraints to the expansion of agricultural production. Pressures from increased urbanization has prevented expansion in the arable area, and competition for land is high [26]. The demand for land is especially strong in eco-fragile areas, because most of the local 
residents rely on farming while agricultural productivity and soil quality fall behind national average levels [27]. In such areas, ecological issues are observed simultaneously with widespread poverty [28]. This is reflected in the poor implementation of eco-environmental policies, ecosystem deterioration, over-grazing, and over-cultivation [29]. The volume of contaminated soil in China is increasing while the environmental remediation industry is still in its infancy, and will need to develop its capacity in order to ensure the green transformation of rural areas [30]. The dilemma is that the intensive use of land is important to the livelihoods of small-sized rural households [27], but sustainable use is demanded by society, because the eco-fragile areas play a crucial role in the provision of multiple ecological services such as air purification, climate regulation, soil stability, and eco-landscapes [31,32].

At the small size of households, income from farming is low. Over 130 million people $(10 \%$ of the population) live below the poverty line, and $97 \%$ of those people live in rural areas. Since the start of reform and opening-up in 1978, an economic boom has helped lift more than 700 million people out of poverty [33]. The Chinese government has made a promise to lift all of the rural residents living below the current poverty line out of poverty by 2020 [34], and has approved the five-year plan that focuses on people living in the nation's 128,000 poor villages and 832 counties [33]. By now, China's government has already made great progress in rural poverty alleviation by implementing integrated rural, agrarian, and land policies. The plan further encourages the development of competitive industries in areas that include agricultural production to help pursue the goal of alleviating poverty [33]. Despite the impressive achievement, in 2016 at least $5.7 \%$ of China's rural population still lived in poverty [35], with that number rising to as much as $10 \%$ in some western regions [36]. The United Nations has consistently emphasized that poverty is a multidimensional phenomenon that requires consideration of not just income, but also access to basic services and problems of exclusion [35]. Although official statistics apparently reveal a substantial reduction in rural poverty, the insensitivity of the poverty line to food price changes has rendered it unable to reflect the consumption power of poor farmers [37]. According to the Chinese definition, people living in poverty are those with a per capita annual income lower than $\$ 335$ [38]. However, many experts, have criticized that level as being too low and subject to several sources of bias, among them the minimum level of caloric requirement, a food bundle's composition, the use of planned prices, and the valuation of non-food expenditures [39]; there have also been complaints that the income-based benchmark that is used to calculate poverty line in China is often unclear and is not always consistent [35]. Some government officials claim that the benchmark used is higher than the World Bank minimum for measuring extreme poverty, but the figures that are offered alternate between $2300 \mathrm{CNY}$ and $2800 \mathrm{CNY}$ per year. Both of these figures are below the World Bank target of $\$ 1.90$ per day [35].

The progress that China has made in poverty alleviation has been accompanied by the emergence of inequality [35]. Since the early 1980s, China has experienced an unusually sharp increase in the gaps between its rich and poor citizens. According to Whyte [40], between 1981-2007, the Gini coefficient in the distribution of net household income in China grew from 0.28 to 0.49 and reached a peak of 0.491 in 2008. According to the National Bureau of Statistics of China [41], income inequality dropped down to 0.4 in 2017, but still remained above the international alert line defined by the United Nations Human Settlements Program [42]. Inequalities exist even between rural areas themselves. Many of them are remote, deprived and lag behind the prosperous east coast. De Janvry and Sadoulet [43] classify marginal rural areas as that with either poor agro-ecological endowments and/or those that are isolated from access to markets and an employment center. Some have closer ties to the urban areas and are designated partners for food production thanks to their proximity and better infrastructure. According to De Janvry and Sadoulet [43], favorable rural areas are defined as those with good agro-ecologies and good connections to a dynamic product and/or labor markets. However, even in the northern parts of China that are classified as the "favorable rural areas", which have developed agricultural production, a high contribution of agriculture to the gross regional product, a high average rural household size, and the highest per capita land resource endowment among China's provinces (Heilongjiang - 3.1 ha per farm in average, Jilin -1.9 ha, Liaoning -0.8 ha, and Inner 
Mongolia Autonomous Region-2.5 ha [44]), the share of the rural population in the province's total population has decreased.

Certain groups are especially vulnerable, such as the elderly and the young, for whom the poverty rate is $7.1 \%$ [35]. Increasingly, among the young people and those of active working age, the migration decision has been viewed as a survival strategy to diversify the range of family incomes [42,45]. Until 1983, China's government had restricted internal migration between rural and urban areas by means of the hukou system of household registration. Chinese citizens have an urban, non-agricultural registration; an urban, agricultural registration; a rural, agricultural registration; or no registration at all [42]. After 1983, the barriers have been gradually easing, which has resulted in the growth of migration flows from rural settlements to cities and suburban areas [46]. The appeal of cities has led some 250 million people to leave the countryside and create a new social class of migrant workers. These are workers who are registered as rural in their hukou, and thus, they are at a major disadvantage in many respects. They have not been accepted or registered as urban, and as such, they are treated unequally in access to social services such as healthcare and social security [40]. That is how poverty in China thrives in this new class of migrant workers.

The migration of rural citizens to cities has had the indirect result of funneling remittances back to rural areas, and thus reducing regional disparities [42]. However, while the effects of migrants' remittances on the standards of rural living have been positive, those from the labor cutback on the sustainable development of rural areas have been dramatically negative. Migration brings several negatives to sustainable development, including: an aging population, lack of labor of high qualification, degradation of population, growing social tensions, the abandonment of rural settlements and agricultural lands, a lowering effectiveness of agricultural production, and a growing environmental load due to the intensive application of fertilizers and the low culture of farming [47]. Rural crisis aggravates when a decrease in the number of rural dwellers results in the degradation of the service sector in rural areas, which in turn instigates a new round of migration outflow [48]. In 2016, the share of rural population in the total population of China decreased down to $43.3 \%$ from $55.7 \%$ in 2006 , and from over $80 \%$ at the beginning of the economic reforms of the 1980 s. The consequences of migration for the social stability and sustainable development of rural areas in China are quite severe: farmers are forced out of their land due to a range of economic and social reasons; they seek additional non-agricultural employment in the cities [49], and thus create a complex situation where villages are even more excluded and drained of their workforce.

The contrasts between "favorable" and "marginal" areas as defined by De Janvry and Sadoulet [43] point to the relevance of a regionally differentiated approach that has to be taken into account when studying the relationships between migration and poverty. This study attempts to reveal the major migration intentions among rural laborers in the relatively well performing northeast of China, as well as develop a portfolio of a typical rural migrant. The idea of the approach is to identify the best-performing rural areas (in terms of agricultural development, economic situation, and welfare of rural dwellers), and reveal the reasons why people nevertheless end up leaving their traditional rural habitats.

\section{Materials and Methods}

Previous research studies have used various methods and largely generated incomplete findings on the causes of rural out-migration. Rozelle et al. [50] assessed the contributions of the income level of those who choose to migrate, chain migration, rural institutions, and human capital to migration. Qin and Liao conducted a systematic review of recent case studies of labor out-migration in rural China [51] that revealed general contextual patterns of migration impacts on agriculture using a qualitative comparative analysis approach. They concluded that migration intensity was influenced by the level of economic development of a rural community, its geographical locality, land resources, and dependence on agriculture. Hao [5] used the cumulative causation of migration theory to conceptualize social expectations for out-migration, and on the contrary, found that the importance of economic development level and wage differentials declines, while social resources 
from migrant networks, along with expectations of out-migration, play an increasingly important role in attracting rural labor to the cities. Li [52] conducted an empirical analysis of interactive relations between rural labor migration and income distribution, and concluded that rural out-migration did not cause deterioration in income distribution, but did narrow the urban-rural income gap. Quite the opposite, Jia et al. [53] demonstrated that there was still a significant number of people living in poverty in rural areas, while the effectiveness of migration on poverty reduction had declined.

In addition to the continuous debate over which particular factors are more important in pushing people out of rural areas, and widely different findings depending on the variables taken into consideration, rural migration drivers differ from one Chinese province to another. Particularly, $\mathrm{Li}$ [52] found evidence that different provinces experience different effects of rural migration on income inequality. Meanwhile, Fan et al. [4] showed that migration was negatively correlated with the level of economic development in the emigrant provinces, and that migration distance was positively correlated with the level of economic development in the immigrant provinces. Pan et al. [45] discovered different effects of migration among western mountainous and eastern plain areas of China, particularly regarding the wage level of rural households and the effects of remittances on agricultural production and income level. Qin [54] demonstrated that labor-migrant and non-labor-migrant households differ significantly in livelihood activities, including agricultural production, agricultural technology use, income and consumption, and resource use and management.

However, until now, no study has revealed the causes of rural out-migration in China's provinces that are seemingly prosperous in terms of agricultural production, the availability of land resources, and rural development. In an attempt to answer this question, a study of principal drivers of rural out-migration has been conducted on the case of three northern provinces of China (Heilongjiang, Jilin, and Liaoning), as well as the Inner Mongolia Autonomous Region.

The study has been conducted in three phases by the employment of the Delphi approach at the first and second stages, along with the questionnaire survey of rural dwellers in selected districts at the third stage. The rationale of using the Delphi approach instead of the available statistics is that Chinese official data are focused too narrowly on income-based approaches to poverty alleviation in rural areas, thereby paying insufficient attention to the multidimensional aspects of rural migration and its relationship to poverty [35]. Accurate measuring of the poverty-migration relationship depends on whether rural citizens remain in poverty for a remarkable portion of their lifetime or a transitory period only. Standard poverty measures ignore such underlying dynamics [55]. Moreover, many of the poverty and migration indicators remain greatly unaccounted for, because rural migrants are not officially recorded in the hukou registration system as those leaving rural areas and settling in the cities. At the level of rural districts, poverty rates are much higher than the official estimates [56], while rural out-migration continues to be seen as an essentially economic issue that can be solved solely through the economic growth of rural territories [35]. Furthermore, the heterogeneous economic development of Chinese provinces, even those located within the common macroregion of China's northeast, creates the need for the regionally differentiated poverty-migration measures. The experts' ranking used in the study helps to consider the unmeasured dimensions of the poverty-migration relationship; in particular, rural districts as rural households may have unmeasured social capital; opportunities for education or health that enhance their potential capability to earn income; or assistance in income from unregistered migrants. Besides, how rural communities organize, and how their activities are planned on a district level, may affect migration [42].

Phase 1: A survey of experts (two per province) representing local government authorities and research institutions. The experts were suggested to rate the Heilongiiang, Jilin, and Liaoning provinces and the Inner Mongolia Autonomous Region on the scale from 0 (the lowest) to 10 (the highest) on five parameters:

- $\quad$ per capita regional production in agriculture $\left(X_{1}\right)$;

- the share of rural population in the total population of the region (the more people live in rural areas, the higher the rating) $\left(X_{2}\right)$; 
- number of urban agglomerations with over 100,000 inhabitants (the fewer cities in the province, the higher the rating) $\left(X_{3}\right)$;

- annual average income per household $\left(X_{4}\right)$;

- the ratio between per capita income in rural and urban areas (the smaller the gap, the higher the rating) $\left(X_{5}\right)$.

The rating $\left(X_{n}\right)$ is an average of all of the expert evaluations; the resulting rating of a region $(X)$ is an arithmetic average $\sum_{n=1}^{5} X$.

Phase 2: A survey of the experts in the highest-rated province. Eighteen experts representing the administrative bodies and research organizations of Heilongjiang Province were surveyed, particularly, two respondents from local government authorities, three respondents from universities of Harbin city, and 13 representatives of the administrative divisions of Heilongjiang Province (one per division). By analogy to Phase 1, the experts were asked to rate 13 prefecture-level divisions of Heilongiiang Province on five parameters:

- number of rural settlements $\left(Y_{1}\right)$;

- the share of employed residents in the agricultural sector within the total number of employed residents $\left(Y_{2}\right)$

- $\quad$ the average size of a household (the bigger a household, the higher the rating) $\left(Y_{3}\right)$;

- $\quad$ the share of income from farming in the aggregated income of households $\left(Y_{4}\right)$;

- infrastructure development in rural areas $\left(Y_{5}\right)$.

Phase 3: A selection of one rural district in each of the three highest-rated administrative divisions. Two selection criteria were implemented: the number of rural inhabitants, and the simultaneous remoteness of the particular district from the administrative center and from Harbin city. In the Heihe, Suihua, and Yichun administrative divisions, Xunke, Mingshui, and Jiayin counties were selected, respectively (Figure 1). In those counties, the heads of rural households (128 people in total, including 41 respondents in Xunke County, 34 in Mingshui County, and 53 in Jiayin County) were asked to fill out the semi-structured questionnaire.

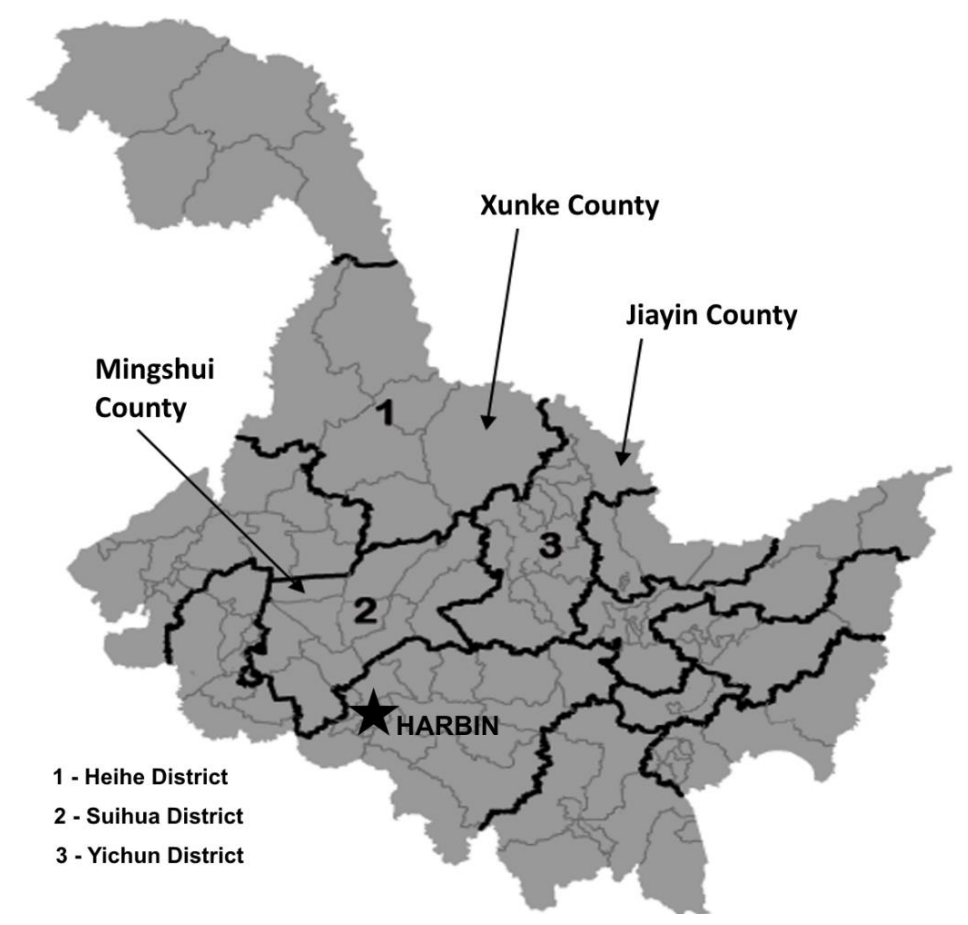

Figure 1. Rural counties of Heilongjiang Province, where the questionnaire surveys have been conducted. (Source: authors' development). 


\section{Results}

At Phase 1, Heilongjiang Province was rated the highest among the four provinces under study (Table 1). While the province received the highest rating on per capita regional product in agriculture $\left(X_{1}\right)$ only, the remaining parameters were also rated rather high, which resulted in the highest average. At Phase 2, the Heihe, Suihua, and Yichun administrative divisions were recognized as the best-performing among the 13 prefecture-level divisions of Heilongjiang Province, in terms of the number of rural settlements (Suihua), share of employed residents in the agricultural sector among the total number of employed residents (Suihua and Heihe), and the share of income from farming in relation to the aggregated income of all households (all three).

Table 1. Expert evaluations of China's northern provinces and administrative divisions of Heilongjiang Province on the level of development of rural territories and agricultural production.

\begin{tabular}{|c|c|c|c|c|c|c|}
\hline Region/Administrative Division & \multicolumn{4}{|c|}{ Parameters } & \multicolumn{2}{|r|}{ Resulting Average } \\
\hline \multicolumn{7}{|c|}{ Phase 1} \\
\hline & $X_{1}$ & $X_{2}$ & $X_{3}$ & $X_{4}$ & $X_{5}$ & $X$ \\
\hline Inner Mongolia & 5.75 & 6.38 & 7.38 & 5.63 & 6.25 & 6.28 \\
\hline Jilin & 6.50 & 7.13 & 6.13 & 6.38 & 5.88 & 6.40 \\
\hline Liaoning & 6.50 & 5.00 & 6.25 & 7.13 & 6.13 & 6.20 \\
\hline Heilongjiang & 7.75 & 7.00 & 6.75 & 6.75 & 6.00 & 6.85 \\
\hline \multicolumn{7}{|c|}{ Phase 2} \\
\hline & $Y_{1}$ & $Y_{2}$ & $Y_{3}$ & $Y_{4}$ & $Y_{5}$ & $Y$ \\
\hline Daxinganling Prefecture & 5.64 & 7.98 & 8.14 & 8.06 & 5.17 & 7.00 \\
\hline Daqing & 6.52 & 5.54 & 6.43 & 5.14 & 8.10 & 6.35 \\
\hline Yichun & 6.98 & 7.51 & 7.55 & 7.96 & 7.14 & 7.43 \\
\hline Mudanjiang & 6.64 & 5.69 & 7.04 & 6.16 & 8.61 & 6.83 \\
\hline Suihua & 7.56 & 8.12 & 8.09 & 8.16 & 7.52 & 7.89 \\
\hline Harbin & 7.12 & 5.17 & 5.04 & 4.69 & 9.01 & 6.21 \\
\hline Hegang & 6.73 & 6.78 & 6.66 & 7.13 & 7.03 & 6.87 \\
\hline Heihe & 7.50 & 8.02 & 7.51 & 8.10 & 7.11 & 7.65 \\
\hline Jixi & 6.64 & 7.42 & 7.23 & 7.06 & 5.93 & 6.86 \\
\hline Jiamusi & 7.13 & 6.92 & 6.96 & 6.58 & 7.08 & 6.93 \\
\hline Qitaihe & 7.10 & 7.15 & 6.58 & 7.19 & 6.55 & 6.91 \\
\hline Qiqihar & 6.41 & 5.13 & 6.14 & 6.90 & 8.19 & 6.55 \\
\hline Shuangyashan & 6.93 & 7.08 & 6.50 & 6.88 & 7.88 & 7.05 \\
\hline
\end{tabular}

Source: Authors' development based on the experts' survey.

At Phase 3, Xunke, Mingshui, and Jiayin counties were selected among the counties of the Heihe, Suihua, and Yichun administrative divisions, respectively, as those with the biggest rural population and located the farthest from Harbin city, as well as from the prefecture-level cities of Aihui (Heihe), Zhaodong and Beilin (Suihua), and Tieli (Yichun). The respondents were asked to answer 10 closed-ended multiple-choice, open-ended, and mixed questions. Processing of the survey results enabled identifying the core migration drivers and developing a portfolio of a typical rural migrant (Table 2).

The majority of the inhabitants of the three counties under investigation who had either ever moved to the cities or planned to migrate are the representatives of the most mobile social groups; they were between 25-45 years old, had years of working experience, and had a certain degree of self-sufficiency. This finding correlates with Zhao et al. [57], who reported modern rural migrants to be more educated and skilled compared with previous generations of leavers. A typical migrant is a male with a family and children, who is often in charge of his old parents, and has a very small plot of land, which taken together force him to seek alternatives to low-margin farming. People tend to migrate to urban areas with their spouses, consume more in urban areas, and send less money back home [57]. In rural areas, such people do not have sources of income other than farming, except for some kind of support from the state (primarily, old age pension) or from relatives. Females are more likely to stay, as the principal roles of a woman in Chinese rural society are housekeeping, livestock management, 
and farming [58]. Another reason for the prevalence of male migration is the specificity of jobs in urban areas that are available for migrants: primarily, construction of industrial and infrastructural facilities.

The majority of migrants have a primary school and, to a lesser degree, secondary education. When moving to the cities, rural migrants enter the strictly segmented urban labor market in which they have very few chances to overstep the limits of a low-skilled and low-paid segment in favor of higher-paid employment opportunities. Therefore, after a certain lapse of time (usually, six months), many migrants, particularly those with families and big land plots, opt to return to their rural habitats, and then migrate somewhere else again in search of a living. This finding corresponds to Hu et al. [59], who discovered that due to the restrictions of the hukou system and the lack of a rural land rental market, people with more children and more land at home were more likely to migrate circularly rather than permanently. Very few people thus commit the future of their families by moving all of their family members to the cities. Instead, they prefer to return to the rural settlements to spend the money earned, or, in the long run, start a small business or invest in the expansion of a farm.

In average, the level of education of rural migrants is lower than those who choose to stay. Since it is very hard to get a high-paid job in the cities, rural migrants do not see a point in education, and are satisfied with elementary reading, counting, and writing skills. In particular, in the Xunke and Jiayin counties, which are located beyond Harbin and other urban agglomerations of Heilongjiang Province, children often drop out of secondary school and move to the cities to help their relatives. It is remarkable that some young people choose to return to the rural area upon graduating a vocational school or even university in a hope of a better employment offer than their less-educated fellow villagers. In Mingshui County, six households reported an interesting practice: income received by one or several family members in the cities was spent on the education of other members of those families in the universities of Harbin city. In such a way, the families implemented a long-term strategy of migration by counting on the employment of at least one member of a family after graduation, and the further move of other members to the city. This finding supports the previous conclusion of Rozelle et al. [50], who demonstrated that being involved in chain migration was a key to facilitating rural out-movement. Chen et al. [60] also report that the elderly play an important role in supporting the migration of younger members.

The prevailing reason of migration emphasized by the majority of the respondents is additional earnings (Table 3). In the cities, rural migrants are involved in the heaviest and dirtiest kinds of jobs; so, many urban people treat them with contempt as the lowest-class workers, who are undereducated and potentially dangerous members of society [61]. However, for the sake of earning money, rural migrants suffer discrimination, poor living conditions, and an unavailability of social services and medical care.

Rural poverty is one of the severest problems of China, as it pushes people from their traditional rural habitats to the cities. However, the study has revealed that the reasons for outflow migration in rural areas are not limited to poverty. Exactly the opposite, the poorest rural people with an average annual income of below $5000 \mathrm{CNY}$ prefer to stay in their settlements since they lack start-up capital, are not aware of the available employment opportunities in the cities, or are afraid of changes to established lifestyle patterns. Poor economic circumstances and an absence of opportunities for the raising of living standards decrease the social and economic activity of rural dwellers [62]. Typical migrants are the representatives of the rural middle class, for whom migration means not so much an alleviation of extreme poverty as an opportunity to increase household welfare. This finding corresponds to Xing and Zhang [63], who conducted a large-scale population survey, and concluded that typical rural-urban migrant was willing to give up some income in order to live in a larger city.

Another economic driver of migration is a reduction of demand for labor. In the process of economic reforms, many small agricultural enterprises that used to be the major employers of rural labor in the 1990s-2000s have undergone privatization and other forms of reorganization, and have thus reduced their demand. As a matter of course, the people of active working age who have been made redundant started to look for employment opportunities out of rural areas. 
Table 2. Distribution of answers to questions 1-7.

\begin{tabular}{|c|c|c|c|}
\hline$\#$ & Question & Answer Choice & Distribution of Answers, the Percentage of the Total \\
\hline \multirow{5}{*}{1.} & \multirow{5}{*}{ Your age } & below 25 & $12.2 \%$ \\
\hline & & 25-35 & $41.5 \%$ \\
\hline & & $35-45$ & $27.7 \%$ \\
\hline & & $45-55$ & $13.5 \%$ \\
\hline & & over 55 & $5.1 \%$ \\
\hline \multirow{2}{*}{2.} & \multirow{2}{*}{ Your gender } & male & $73.4 \%$ \\
\hline & & female & $26.6 \%$ \\
\hline \multirow{6}{*}{3.} & \multirow{6}{*}{ Level of your education } & primary & $39.2 \%$ \\
\hline & & secondary & $20.4 \%$ \\
\hline & & vocational & $15.6 \%$ \\
\hline & & higher & $10.7 \%$ \\
\hline & & & partially completed secondary education $-8.4 \%$; \\
\hline & & other (specify) & $\begin{array}{c}\text { partially completed vocational education- }-3.5 \% \text {; } \\
\text { no education }-2.2 \% \text {. }\end{array}$ \\
\hline \multirow{5}{*}{4.} & \multirow{5}{*}{$\begin{array}{l}\text { How many members are there in your } \\
\text { family (parents, spouses, and children)? }\end{array}$} & 2 people & $9.7 \%$ \\
\hline & & 3-5 people & $44.5 \%$ \\
\hline & & over 5 people & $18.4 \%$ \\
\hline & & & single- $12.8 \%$ \\
\hline & & other (specify) & support of parents- $14.6 \%$. \\
\hline \multirow{4}{*}{5.} & \multirow{4}{*}{ Size of your household } & below 1 ha & $64.5 \%$ \\
\hline & & $1-5$ ha & $24.7 \%$ \\
\hline & & 5-10 ha & $9.6 \%$ \\
\hline & & over 10 ha & $1.2 \%$ \\
\hline \multirow{4}{*}{6.} & \multirow{4}{*}{$\begin{array}{l}\text { What is an annual average income of } \\
\text { your household per family member? }\end{array}$} & below $5000 \mathrm{CNY}$ & $48.6 \%$ \\
\hline & & 5000-10,000 CNY & $33.4 \%$ \\
\hline & & $10,000-15,000 \mathrm{CNY}$ & $15.9 \%$ \\
\hline & & over $15,000 \mathrm{CNY}$ & $2.1 \%$ \\
\hline & & & no off-farm income- $31.7 \%$ \\
\hline 7. & $\begin{array}{l}\text { Do you have any off-farm } \\
\text { sources of income? }\end{array}$ & specify the sources of off-farm income, if any & $\begin{array}{l}\text { state support-28.9\%; } \\
\text { small business (shop, cafeteria, personal services)-20.6\%; }\end{array}$ \\
\hline & & & support by relatives- $-18.8 \%$ \\
\hline
\end{tabular}

Source: Authors' development based on the households survey. 
Table 3. Distribution of answers to questions 8-10.

\begin{tabular}{|c|c|c|c|}
\hline \# & Question & Answer Choice & Distribution of Answers, the Percentage of the Total \\
\hline 8. & $\begin{array}{c}\text { Have you or the members of your family ever migrated to } \\
\text { urban areas to earn money? }\end{array}$ & $\begin{array}{c}\text { yes } \\
\text { no }\end{array}$ & $\begin{array}{l}59.7 \% \\
40.3 \%\end{array}$ \\
\hline 8.1. & If yes, which reasons have prompted you to migrate? & specify the reasons & $\begin{array}{c}\text { earnings-73.4\%; } \\
\text { rural unemployment-9.8\%; } \\
\text { low quality of life in a rural area-8.6\%; } \\
\text { underdeveloped rural infrastructure-5.9\%; } \\
\text { urban attractions-2.3\%. }\end{array}$ \\
\hline 8.2 . & $\begin{array}{c}\text { For how long have you or the members of your family } \\
\text { migrated to urban areas? }\end{array}$ & $\begin{array}{l}\text { less than } 1 \text { month } \\
1-6 \text { months } \\
\text { over } 6 \text { months }\end{array}$ & $\begin{array}{c}5.9 \% \\
57.4 \% \\
36.7 \%\end{array}$ \\
\hline 8.3. & Which reasons have prompted you to return to a rural area? & specify the reasons & $\begin{array}{c}\text { spend time with the family-52.5\%; } \\
\text { help family members (seasonal farming)-24.7\%; } \\
\text { hard working conditions in the city- }-11.9 \% \text {; } \\
\text { start a business in a rural area- } 6.1 \% ; \\
\text { have not been able to find employment in the } \\
\text { city }-4.8 \% \text {. }\end{array}$ \\
\hline 8.4 . & Do you plan to migrate in the future? & $\begin{array}{l}\text { yes } \\
\text { no }\end{array}$ & $\begin{array}{l}76.1 \% \\
23.9 \%\end{array}$ \\
\hline 9. & If you have not migrated, do you have such an intention? & $\begin{array}{l}\text { yes } \\
\text { no }\end{array}$ & $\begin{array}{l}42.6 \% \\
57.4 \%\end{array}$ \\
\hline 10. & If you do not plan to leave, what retains you in the rural area? & specify the reasons & $\begin{array}{l}\text { unwillingness to change a life, a continuation of } \\
\text { economic activity (farming, animal husbandry)-38.4\% } \\
\text { high costs associated with migration-25.5\%; } \\
\text { lack of awareness about urban life and } \\
\text { employment-20.4\%; } \\
\text { unwillingness to leave comfort zone- }-15.7 \% \text {. }\end{array}$ \\
\hline
\end{tabular}


The low social standing of a rural dweller has been reported as the core social driver of rural migration. Even despite the often inhuman living conditions for migrants in the cities, people still view migration as a social ascent. A gap in perceptions of the rural and urban way of life is largely cultivated by mass media, which demonstrate the economic progress of China, rapid urbanization, and the inviting attractions of big cities. This contrast is felt by rural dwellers, particularly in the less developed northern provinces compared with the coastal regions of the country, and galvanizes people into moving.

Many respondents have also emphasized a gap in the level of infrastructure development between rural and urban areas along with the low quality of social services in rural districts, particularly, medical care. In the majority of households, migrant workers' remittances allow paying for the medical care of family members in rural areas, which would otherwise be unaffordable.

\section{Discussion}

Contemporary rural development policies are much broader than they were in the early 2000s. They shifted from agriculture itself to a broader spectrum, which included the social and economic situation in rural territories, development of rural infrastructure, employment and involvement of rural households into economic activities, rural tourism and other alternative sources of income, environmental and recreational issues, etc. [64]. The effectiveness of such policies directly affects the living standards of rural people, the social and demographic situation in rural areas, food security, social and economic control over rural territories, and the development of traditional cultures and the rural way of life [65].

China is a developing economy with a progressively increasing degree of industrialization. However, the importance of agriculture is traditionally high to China, as it implements three principal social functions, i.e., an essential lifeline and social protection of the rural population, an employment for a vast number of people, and a means of decreasing rural poverty [66].

Due to a large population, China's social welfare system fails to guarantee a high level of social protection for all rural dwellers, while agricultural production provides an alternative mechanism of social security. For Chinese rural people, agriculture is not only a source of employment, as land is not only a means of production [67], but the issue of how rural households allocate labor resources among different on-farm and off-farm activities has been emerging as a fundamental factor of sustainable rural and agricultural development as China undergoes economic reforms $[64,68]$. A large volume of agricultural production, along with the world's largest population, emphasizes the scantiness of agricultural resources per capita. The Chinese government has made a point of retaining lands in agricultural production, since the country loses areas under cultivation because of their withdrawal from agriculture for the purpose of constructing industrial facilities, quarries, roads, and other infrastructure objects. Rural-urban land conversion presents a challenge to the ecological system, because many ecosystem services provided by agricultural land are lost in the process of conversion [69]. China's land policy envisages stabilization, and even an increase of arable area by means of tilling wild land in the northern and western provinces. However, the environmental pollution in rural areas is increasingly serious, which has become a constraint against the increase of agricultural production and the sustainable development of the rural economy in China. According to the Organisation for Economic Co-operation and Development (OECD) and FAO [26], 70\% of China's arable land is in low-yield farmland, and nearly $20 \%$ of the arable land in the total is polluted to various degrees. Yang and Meng [70] reported random livestock excrement disposal, low straw utilization, and the continuous growth of household garbage throughput as the major problems of rural environment pollution in northern China, particularly, in Heilongjiang Province.

Migration to urban areas has triggered tremendous land-use changes, reshaped the structure of rural households, and created the so-called "divided households" [60] with individuals who consider themselves as living in both rural and urban areas. The land's original ecosystem degrades as people leave the countryside, and rural-urban land conversion destroys the biological community, soils, water 
flow, and surface structure of agricultural lands [71,72]. The government has been introducing various programs in an attempt to steer land allocation to satisfy not only rural households' needs for the development of agricultural production, but also the provision of ecosystem services [27,73]. However, Feng et al. [74] and Uchida et al. [75] reported that national programs that were directed at ecological conservation had constrained the economic activities of local households on land use.

According to Nath et al. [25], by 2030, China will need to increase agricultural lands under crops by $21 \%$ to meet the increasing internal demand for food. The Chinese government has tried to consolidate agricultural land through the land rental market with the explicit intention of fostering new agricultural management subjects and improving agricultural productivity [7]. However, rural-urban land conversion in the process of the urbanization in China causes an ongoing decrease in agricultural land, resulting in the loss of its original ecosystem services [76]. In their attempts to commercialize agricultural production, small-scale farmers heavily use fertilizers and highly toxic pesticides [77]. So far, China's remarkable increase in agricultural production has been credited to intensive farming due to soil degradation. China has one of the world's highest rates of chemical fertilizer use per hectare [77], but agricultural activities continue yielding modest returns, while a small-size rural household often only produces enough to feed itself. Although Meng and Zhao [78] found that landholding reduced the likelihood of permanent migration and had an effect on temporary migration decisions, our survey of rural dwellers in Heilongjiang Province demonstrated that labor migration had a significant negative effect on households renting the land, as even those farmers who had high agricultural capacity tend to migrate. This result is in line with findings by Glauben et al. [55], who discovered that Chinese rural households operating on relatively larger farms showed a higher probability to be persistently poor, as well as Gustaffson and Ding [79], who found that a higher probability to be permanently poor was linked to larger households. As long as cheap labor is still plentiful in rural areas, large farms have no incentive to increase wages. Instead, they increase the level of mechanization, thereby releasing the "principal labor units" (i.e., males in their prime) from agriculture [80], while the relatively labor-intensive operations (i.e., applying fertilizers and chemicals and watering) still mainly rely on the "auxiliary labor" (i.e., women and the elderly) [80], which remains abundant in the countryside. Although the hired labor market emerged during the transition and households began to hire labor [68], the capacity of small-sized rural households to absorb the released labor is fairly low. The Chinese government has been extending the measures to increase farmers' incomes, including transfers associated with minimum procurement prices for rice and wheat, and with a growing range of commodities covered by market interventions mechanisms [26]. However, the amount of transfers has fluctuated significantly over the past years as a result of the government's policy to reduce price volatility compared with international markets. Thus, high international prices for agricultural commodities were only partly transmitted to domestic markets, resulting in a significant fall in measured market price support to farmers [26].

Poor households lack the necessary assets to effectively participate in value chains [81]. In an attempt to increase returns on their scarce resources, small-scale farmers often choose alternative income-generating activities, such as trying out new crops. However, such trials bear certain risks, as poor households may have little buffer in their resources. Moreover, success depends not only on aspects of production itself, but also on various conditions within and around the respective value chains [81]. Particularly, Glauben et al. [55] revealed a high influence of spatial characteristics on rural poverty and migration. Whereas rural settlements located close to urban areas ("favorable territories" [43]) are associated with a lower probability to be poor in the long-term, the unutilized labor capacity has an increasing effect on this probability. Similarly, the settlements with a higher share of migrating inhabitants are also the home of more long-term poor households [55]. Even though the "favorable" territories offer better opportunities in terms of the development of agricultural production and employment, poor small-sized households still have low asset endowments (especially education, land, and social capital), and consequently low capacity to take advantage of these opportunities. Non-functioning factor markets and poor inclusion to the value chains limit the full exploitation 
of the production potential of rural households [55]. As a result, land endowment and reliance on cropping as a single-household business increase poverty persistence, and drive people to seek off-farm employment in cities.

According to Ye [8], motivations for migrating from the countryside are highly complex, as those who migrate often do so because of either economic pushes resulting from the commodification of subsistence, or social causes. The study has confirmed that the core drivers of migration are of either a social or economic nature. The survey results support the findings of Chen and Liu [82], who revealed that while the settlement intention of the first-generational migrants was more driven by the socio-cultural conditions, economic incentives were more important for the new generation of rural migrants. Mohabir et al. [6] also reported that younger people from rural villages migrated to the cities in search of urban economic opportunities and to escape rural poverty. Among economic drivers, migrants are encouraged by the rural-urban income gap, which supports the findings of Zhang and Song [83].

Han [84] conducted a regression analysis of economic variables, including years prepared for moving between rural and urban areas, and identified the hukou conversion, family separation, and job opportunity as the main barriers that prevent rural migrants from transforming into urban citizens. However, the study has demonstrated that rural migration is not only restricted by administrative regulations, since people continue migrating even under the hukou registration system. Chen and Hamori [85] describe such a situation as China's "new dual labor market", which shifts to informal rural-urban migration versus formal rural workers set up in the cities. In furtherance of the findings of Chen et al. [60], non-administrative barriers to rural out-migration have been revealed, particularly, the disparities in the level of education, healthcare, and social welfare between rural and urban areas. The findings of the study are also in line with Zhang et al. [86], who identified the differences in educational attainment, work experience, distribution across the industry, and occupation as the major causes of the wage gap between rural and urban workers.

In view of such restrictions, the involvement of rural dwellers in agricultural production helps to reduce unemployment. During the global recession of 2008-2009, many rural migrants were forced to return to rural areas; agricultural employment mitigated the effects of the crisis for a considerable part of the population [87]. Mohabir et al. [6] registered return migration from urban areas back to rural settlements during the periods of slow economic development. Thus, the rural way of life provides the minimal level of social welfare and employment. In China, about $40 \%$ of all employment is concentrated in rural areas [44]. Agriculture is the major source of income for the millions of rural dwellers. In the less developed northern and western provinces of the country (compared to the high-industrialized southern and eastern provinces), the share of income from farming in the overall income of rural people is over $59 \%$ (northern provinces) and $54 \%$ (western provinces) (Table 4).

Table 4. Structure of households' income in selected regions of China in 2016, \%.

\begin{tabular}{|c|c|c|c|c|}
\hline Regions/Provinces & Wage & Income from Farming & Property Income & Social Transfers \\
\hline $\begin{array}{l}\text { Eastern provinces } \\
\text { (Shandong, Jiangsu, Anhui, Zhejiang, } \\
\text { Jiangxi, Fujian, Guangdong, Hainan, } \\
\text { Taiwan, Xianggang, Aomen) }\end{array}$ & 50.6 & 38.0 & 4.4 & 7.0 \\
\hline $\begin{array}{l}\text { Central provinces } \\
\text { (Shanxi, Shaanxi, Henan, Hubei, } \\
\text { Chongqing Municipality, Sichuan, } \\
\text { Hunan, Guizhou, Yunnan, Guangxi } \\
\text { Zhuang Autonomous Region, } \\
\text { Ningxia Hui Autonomous Region) }\end{array}$ & 40.7 & 51.1 & 2.0 & 6.1 \\
\hline $\begin{array}{l}\text { Western provinces } \\
\text { (Qinghai, Gansu, Xinjiang Uyghur } \\
\text { Autonomous Region, Tibet } \\
\text { Autonomous Region) }\end{array}$ & 33.9 & 54.4 & 2.6 & 9.1 \\
\hline $\begin{array}{l}\text { Northern provinces } \\
\text { (Heilongjiang, Jilin, Liaoning, Hebei, } \\
\text { Tianjin Municipality, Inner Mongolia } \\
\text { Autonomous Region) }\end{array}$ & 25.3 & 59.7 & 5.0 & 10.0 \\
\hline
\end{tabular}

Source: Authors' development based on the National Bureau of Statistics of China [88]. 
In modern industrializing China, rural poverty exists, particularly in the central and western regions, because economic development has been largely confined to the east [89]. In the poorest rural households, the essential share of income is contributed by low productive farming. During the explosive economic growth and industrialization of China in the 1990-2000s, a large number of rural dwellers migrated to urban areas, which helped to reduce rural poverty by means of the remittances by migrants to their families. $\mathrm{Li}$ [52] indicated that rural migration made a contribution to the growth of rural income, not only by raising the labor productivity of migrant workers, but also by permitting a more efficient allocation of the remaining, non-migrating workers. In the case of northeast China, Rozelle et al. [90] discovered that migration significantly increased the income of households without self-employment, but had a negative impact on the total income of households with both farm and self-employed income. Li [91] confirmed the findings of Rozelle et al. [90], which indicated that although remittances had a positive effect on agricultural output and income, the overall effect of labor migration was negative due to the reduction of the rural labor force.

With the development of economic reforms in China, rural poverty has entered a new phase. Its new feature is an increase of a gap between the levels of income in rural and urban areas (Figure 2), as well as in the industrialized coastal provinces and inner parts of the country [92].

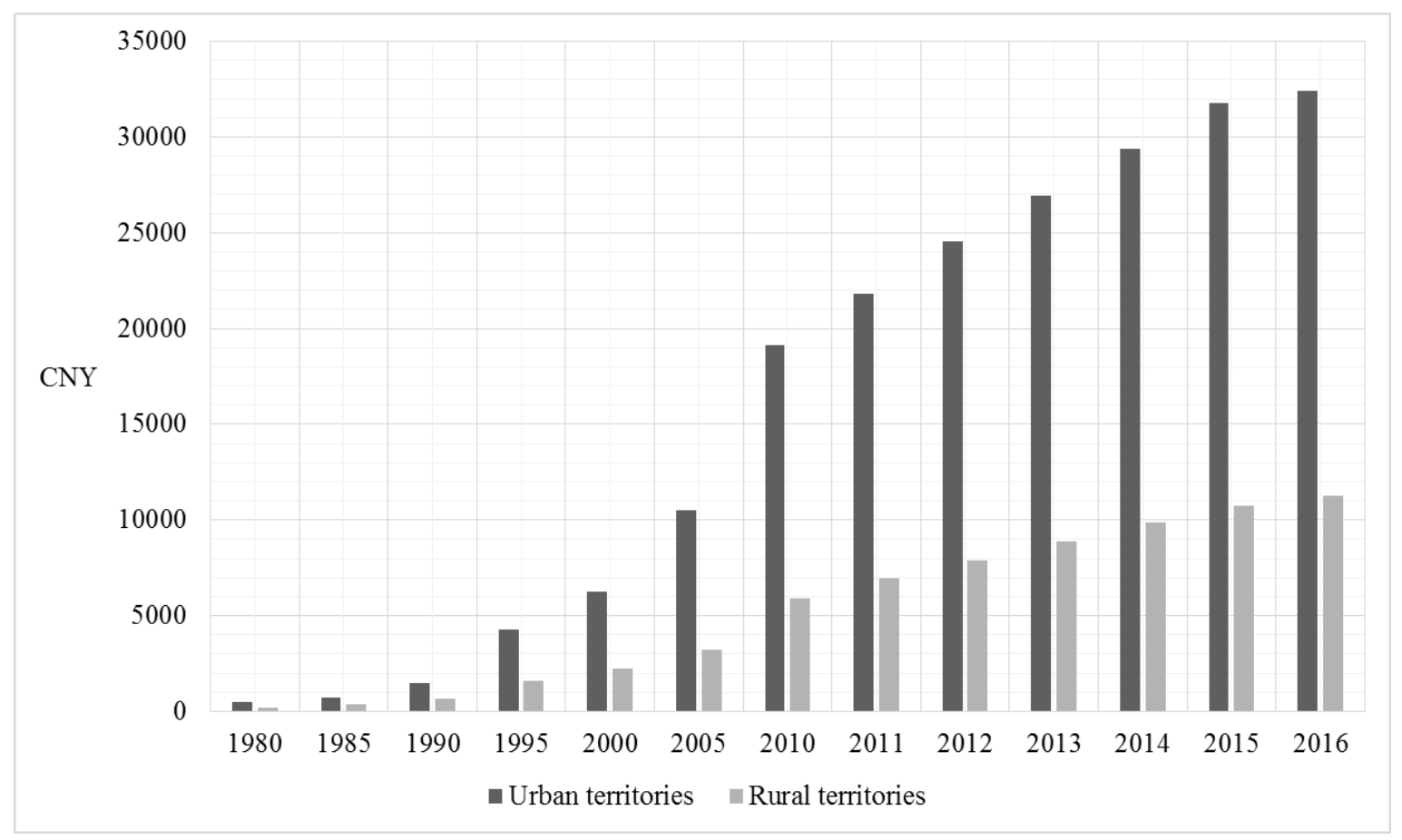

Figure 2. Per capita income in rural and urban territories of China from the start of economic reforms until 2016, CNY. (Source: authors' development based on the National Bureau of Statistics of China [88]).

Even by the 1980s, urban per capita incomes were already growing at more than double the rate of rural farm incomes, and the reforms have further widened the gap [93]. Despite the growth of per capita income in rural areas, particularly in the previous decade, the income gap between rural and urban areas increases. The national average rural-urban income ratio increased from 1:2.20 in 1990 up to 1:2.95 in 2016. Migrants only earn about 50\% of urban workers' income. In many cases, such a wage gap is explained by labor market discrimination against rural migrants [86]. In relation to particular provinces, annual average per capita income varies from 20,000 CNY in eastern provinces to only $7000 \mathrm{CNY}$ in central and western provinces of China (Figure 3). 


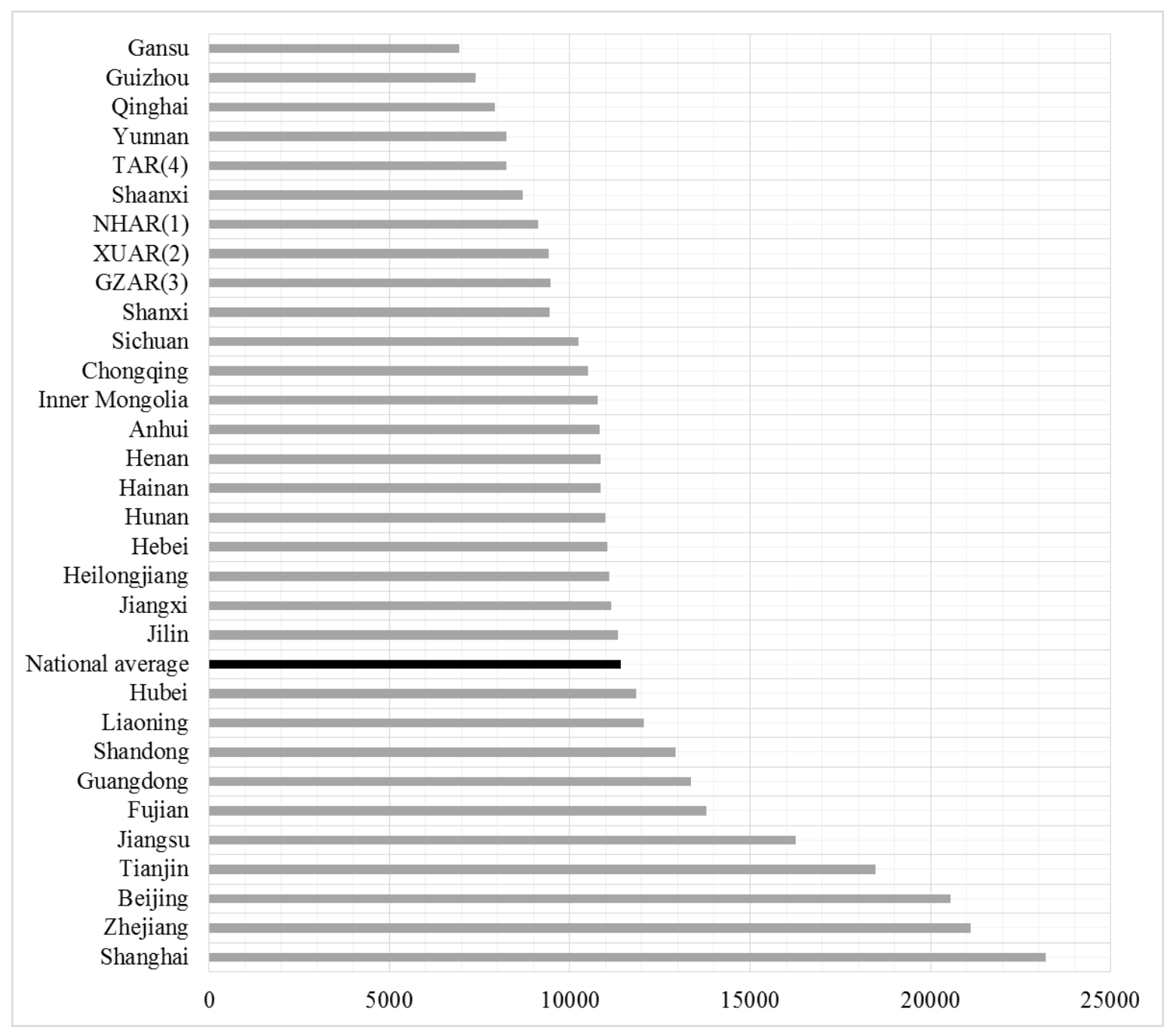

Figure 3. Annual average per capita income in rural territories of China's provinces in 2016, CNY. (Source: authors' development based on the National Bureau of Statistics of China [88]). (Note: (1) Ningxia Hui Autonomous Region; (2) Xinjiang Uyghur Autonomous Region; (3) Guangxi Zhuang Autonomous Region; (4) Tibet Autonomous Region).

Industrialization, along with urbanization had taken a foothold in China by the time that industrial labor productivity rose. In rural areas, labor efficiency remained low compared to industry standards. Knight et al. [94] registered the rural-urban disparities in not only income, but also in labor productivity, infrastructure development, and social welfare. Commonly, migrants from rural areas cannot get employment in full parity with urban citizens. Consequently, the majority of rural migrants fail to fit into the urban environment, and return to rural areas upon retirement. Even better access to urban social benefits results in only a moderate increase in the number of rural individuals intending to settle permanently in the cities [78]. Chen and Liu [82] revealed that although migrants with better human capital were more inclined to settle down in cities, socio-cultural attachment played an important role in determining migrant settlement intentions. Hu et al. [59] also found that more educated and more experienced migrants tend to become permanent urban residents, while the relationship between age and the probability of permanent migration was inversely U-shaped. Therefore, the study has demonstrated that the rural economy loses labor among those of active working age, as well as experiences additional burden as the migrants of an unemployable age return to their settlements. 


\section{Conclusions}

One of the world's lowest land ratios per capita, a lack of arable land, environmental pollution, and rural poverty constrain the increase of agricultural production and threaten the sustainable development of the rural areas of China. Although the migration of excessive rural labor to the cities eases social and economic tensions by providing people with employment and income, as well as increases the land-to-population ratio in rural areas, it also results in the outflow of the most active part of the labor force, i.e., young people of prime working age. The study has demonstrated that a typical migrant is a "landless" male between 25 and 45 years old, with working experience, a family, and children. His migration decision is influenced by the rural-urban income gap, poverty, a reduction of demand for labor in rural areas, underdeveloped infrastructure, the low quality of social services in rural settlements, and the low social standing of rural dwellers. In rural areas, sustainability is conditioned by not only land management, conservation, responsible farming practices, and environmental protection, but also most significantly by a retention of rural labor. The measures aimed at the retention of rural people in their traditional habitats should include the diversifying the rural economy and increasing the investment attractiveness of rural settlements as the local centers of rural development; supporting farmers; developing the non-agricultural sectors, including local crafts and rural tourism; and improving rural infrastructure, including transport, communications, and medical care. It is important to conduct periodic surveys to monitor the effects of particular policy measures on addressing the root causes of rural migration. Having a better picture of migration intentions may help policymakers understand how many people permanently float between rural settlements and cities, bypassing the hukou regulations, and which particular factors encourage some of them to start migration while preventing others from leaving rural communities. The approach developed and tested in this study has allowed revealing the core drivers of migration from the relatively well-performing rural areas, which makes it applicable in the monitoring of migration sentiments among rural dwellers and addressing them respectively.

Author Contributions: T.G. designed research framework and analyzed the data; A.I. performed the data collection; V.E. developed the questionnaire and wrote the paper.

Funding: This research was funded by the Fundamental Research Funds for the Central Universities, China, grant number HEUCFJ170901.

Conflicts of Interest: The authors declare no conflict of interest.

\section{References}

1. Erokhin, V.; Heijman, W.; Ivolga, A. Sustainable Rural Development in Russia through Diversification: The Case of the Stavropol Region. Visegr. J. Bioecon. Sustain. Dev. 2014, 3, 20-25. [CrossRef]

2. Gao, T. Food Security and Rural Development on Emerging Markets of Northeast Asia: Cases of Chinese North and Russian Far East. In Establishing Food Security and Alternatives to International Trade in Emerging Economies; Erokhin, V., Ed.; IGI Global: Hershey, PA, USA, 2017; pp. 155-176.

3. Kleinwechter, U. Rural-Urban Migration in China: An Analytical Framework of Migrants' Contributions to Rural Development. J. Altern. Perspect. Soc. Sci. 2012, 4, 757-789.

4. Fan, X.; Liu, H.; Zhang, Z.; Zhang, J. The Spatio-Temporal Characteristics and Modeling Research of Inter-Provincial Migration in China. Sustainability 2018, 10, 618. [CrossRef]

5. Hao, L. Cumulative Causation of Rural Migration and Initial Peri-Urbanization in China. Chin. Soc. Rev. 2012, 44, 6-33. [CrossRef] [PubMed]

6. Mohabir, N.; Jiang, Y.; Ma, R. Chinese Floating Migrants: Rural-Urban Migrant Labourers' Intentions to Stay or Return. Habitat Int. 2017, 60, 101-110. [CrossRef]

7. Ji, X.; Qian, Z.; Zhang, L.; Zhang, T. Rural Labor Migration and Households' Land Rental Behavior: Evidence from China. China World Econ. 2018, 26, 66-85. [CrossRef]

8. Ye, J. Stayers in China's “Hollowed-Out” Villages: A Counter Narrative on Massive Rural-Urban Migration. Popul. Space Place 2017, e2128. [CrossRef] 
9. Zhou, Z. Achieving Food Security in China: Past Three Decades and Beyond. China Agric. Econ. Rev. 2010, 3, 251-275. [CrossRef]

10. Zhou, Z.; Liu, H.; Cao, L.; Tian, W.; Wang, J. Food Consumption in China: The Revolution Continues; Edward Elgar Publishing: Cheltenham, UK, 2014.

11. Liu, J.; Diamond, J. China's Environment in a Globalizing World. Nature 2005, 435, 1179-1186. [CrossRef] [PubMed]

12. Zhu, Y. International Trade and Food Security: Conceptual Discussion, WTO and the Case of China. China Agric. Econ. Rev. 2016, 8, 399-411. [CrossRef]

13. Yu, W.; Elleby, C.; Zobbe, H. Food Security Policies in India and China: Implications for National and Global Food Security. Food Secur. 2015, 7, 405-414. [CrossRef]

14. Yu, Y.; Feng, K.; Hubacek, K.; Sun, L. Global Implications of China's Future Food Consumption. J. Ind. Ecol. 2016, 20, 593-602. [CrossRef]

15. Luan, Y.; Cui, X.; Ferrat, M. Historical Trends of Food Self-Sufficiency in Africa. Food Secur. 2013, 5, $393-405$. [CrossRef]

16. Ghose, B. Food Security and Food Self-Sufficiency in China: From Past to 2050. Food Energy Secur. 2014, 3, 86-95. [CrossRef]

17. Zhang, J. China's Success in Increasing Per Capita Food Production. J. Exp. Bot. 2011, 32, 1-5. [CrossRef] [PubMed]

18. Zeng, C.; Deng, X.; Dong, J.; Hu, P. Urbanization and Sustainability: Comparison of the Processes in "BIC" Countries. Sustainability 2016, 8, 400. [CrossRef]

19. Kneller, R.; Morgan, C.W.; Kanchanahatakij, S. Trade Liberalisation and Economic Growth. World Econ. 2008, 31, 701-719. [CrossRef]

20. Long, H.; Liu, Y.; Li, X.; Chen, Y. Building New Countryside in China: A Geographical Perspective. Land Use Policy 2010, 27, 457-470. [CrossRef]

21. Heilig, G.K.; Hubacek, K.; Sun, L. Sustainable Regional and Rural Development in China: Where Do We Stand? International Institute for Applied Systems Analysis: Laxenburg, Austria, 2001.

22. Krasova, E.; Sun, Y. Position and Role of North-Eastern Provinces in the Economic Development of Modern China. Vector Sci. Tolyatty State Univ. 2016, 27, 55-61. [CrossRef]

23. Chen, J.; Fleisher, B.M. Regional Income Inequality and Economic Growth in China. J. Comp. Econ. 1996, 22, 141-164. [CrossRef]

24. Ma, L. Sustainable Development of Rural Household Energy in Northern China. J. Sustain. Dev. 2011, 5, 115-124. [CrossRef]

25. Nath, R.; Luan, Y.; Yang, W.; Yang, C.; Chen, W.; Li, Q.; Cui, X. Changes in Arable Land Demand for Food in India and China: A Potential Threat to Food Security. Sustainability 2015, 7, 5371-5397. [CrossRef]

26. Organisation for Economic Co-operation and Development; Food and Agriculture Organization of the United Nations. OECD-FAO Agricultural Outlook 2013-2022; OECD: Paris, France, 2013.

27. Liu, M.; Heijman, W.; Zhu, X.; Dries, L.; Huang, J. Individual and Social Optima of Rural Land Allocation by Stakeholders: A Case Study on Eco-Fragile Areas of Northern China. Rangel. J. 2016, 38, 57-72.

28. Ran, S.; Jin, J.; Zeng, S. Division of Vulnerable Ecology Region Type and Analysis of Its Characteristic. China Popul. Resour. Environ. 2001, 11, 73-77.

29. Han, J.G.; Zhang, Y.J.; Wang, C.J.; Bai, W.M.; Wang, Y.R.; Han, G.D.; Li, L.H. Rangeland Degradation and Restoration Management in China. Rangel. J. 2008, 30, 233-239. [CrossRef]

30. Kennedy, C.; Zhong, M.; Corfee-Morlot, J. Infrastructure for China's Ecologically Balanced Civilization. Engineering 2016, 2, 414-425. [CrossRef]

31. Smith, H.F.; Sullivan, C.A. Ecosystem Services within Agricultural Landscapes-Farmers' Perceptions. Ecol. Econ. 2014, 98, 72-80. [CrossRef]

32. Soy-Massoni, E.; Langemeyer, J.; Varga, D.; Saez, M.; Pinto, J. The Importance of Ecosystem Services in Coastal Agricultural Landscapes: Case Study from the Costa Brava, Catalonia. Ecosyst. Serv. 2016, 17, 43-52. [CrossRef]

33. Ministry of Agriculture and Rural Affairs of the People's Republic of China. China's Cabinet Issues Five-Year Plan for Poverty Alleviation. Available online: http:/ / english.agri.gov.cn/news/dqnf/201612/t20161205_ 237563.htm (accessed on 16 April 2018). 
34. China Radio International. China Promises to End Poverty by 2020. Available online: https://gbtimes.com/ china-promises-end-poverty-2020 (accessed on 19 April 2018).

35. United Nations General Assembly. Report of the Special Rapporteur on Extreme Poverty and Human Rights on His Mission to China. Available online: https:/ / documents-dds-ny.un.org/doc/UNDOC/GEN/G17/ 076/79/PDF/G1707679.pdf?OpenElement (accessed on 17 April 2018).

36. Phillips, T. China to Move Millions of People from Homes in Anti-Poverty Drive. Available online: https: / / www.theguardian.com/world/2018/jan/07/china-move-millions-people-homes-anti-poverty-drive (accessed on 19 April 2018).

37. Yang, L. Poverty Line in China Rural Areas: A Critical Reappraisal. J. Poverty 2010, 14, 329-346.

38. Li, W. China to Reduce Its Rural Poverty Population by over 10 Million in 2018. Available online: https: / /gbtimes.com/china-to-reduce-its-rural-poverty-population-by-over-10-million-in-2018 (accessed on 19 April 2018).

39. Park, A.; Wang, S. China's Poverty Statistics. China Econ. Rev. 2001, 12, 384-398. [CrossRef]

40. Whyte, M.K. Soaring Income Gaps: China in Comparative Perspective. Dædalus 2014, 143, 39-52. [CrossRef]

41. People's Daily Online. China's Gini Coefficient Exceeded 0.4 in 2017. Available online: http:/ / en.people.cn/ n3/2018/0206/c90000-9424307.html (accessed on 19 April 2018).

42. United Nations Human Settlements Programme. Urbanization and Development: Emerging Futures; UN-Habitat: Nairobi, Kenya, 2016.

43. De Janvry, A.; Sadoulet, E. Toward a Territorial Approach to Rural Development. J. Agric. Dev. Econ. 2007, 4, 66-98.

44. Erokhin, V. Development of Rural Territories in the Far East, Russia and Heilongjiang Province, P.R. China. Agric. Bull. Stavrop. Reg. 2016, 23, 256-260.

45. Pan, Z.; Xu, W.; Huang, Z.; Wang, G. The Effects of Labour Migration on Rural Household Production in Inland China: Do Landform Conditions Matter? Popul. Space Place 2017, e2086. [CrossRef]

46. Cherkasova, O. Social and Economic Development of Rural Territories of China. Agri-ind. Prod. Exp. Probl. Dev. Perspect. 2008, 3, 37-46.

47. Christiaensen, L.; Demery, L.; Kuhl, J. The (Evolving) Role of Agriculture in Poverty Reduction. J. Dev. Econ. 2011, 96, 239-254. [CrossRef]

48. Bondarenko, L. Development of Rural Territories of Russia: Estimates, Opinions, Expectations. Sociol. Stud. 2016, 3, 76-82.

49. Ivolga, A. Diversification of Income Sources of Rural Population as a Way to Sustainable Rural Development of Stavropol Region. Agric. Bull. Stavrop. Reg. 2014, 13, 102-107.

50. Rozelle, S.; Shen, M.; Hughart, A.; Giles, J. Leaving China's Farms: Survey Results of New Paths and Remaining Hurdles to Rural Migration. China Quart. 1999, 158, 367-393. [CrossRef]

51. Qin, H.; Liao, T.F. Labor Out-Migration and Agricultural Change in Rural China: A Systematic Review and Meta-Analysis. J. Rural Stud. 2016, 47, 533-541. [CrossRef]

52. Li, S. Effects of Labor-out Migration on Income Growth and Inequality in Rural China. Dev. Soc. 2009, 28, 93-114.

53. Jia, P.; Du, Y.; Wang, M. Rural Labor Migration and Poverty Reduction in China. China World Econ. 2017, 25, 45-64. [CrossRef]

54. Qin, H. Rural-to-Urban Labor Migration, Household Livelihoods, and the Rural Environment in Chongqing Municipality, Southwest China. Hum. Ecol. 2010, 38, 675-690. [CrossRef] [PubMed]

55. Glauben, T.; Herzfeld, T.; Rozelle, S.; Wang, X. Persistent Poverty in Rural China: Where, Why, and How to Escape? World Dev. 2012, 40, 784-795. [CrossRef]

56. Zhang, C.; Xu, Q.; Zhou, X.; Zhang, X.; Xie, Y. Are Poverty Rates Underestimated in China? New Evidence from Four Recent Surveys. China Econ. Rev. 2014, 31, 410-425. [CrossRef]

57. Zhao, L.; Liu, S.; Zhang, W. New Trends in Internal Migration in China: Profiles of the New-Generation Migrants. China World Econ. 2018, 26, 18-41. [CrossRef]

58. Wu, H.-C. Local Traditions, Community Building, and Cultural Adaptation in Reform Era Rural China; Harvard University: Cambridge, UK, 2014.

59. Hu, F.; Xu, Z.; Chen, Y. Circular Migration, or Permanent Stay? Evidence from China's Rural-Urban Migration. China Econ. Rev. 2011, 22, 64-74. [CrossRef] 
60. Chen, F.; Lucas, H.; Bloom, G.; Ding, S. Household Structure, Left-Behind Elderly, and Rural Migration in China. J. Agric. Appl. Econ. 2016, 3, 1-19.

61. Ping, H.; Pieke, F.N. China Migration Country Study; Refugee and Migratory Movements Research Unit: Dhaka, Bangladesh, 2003.

62. Konev, Y.; Belonozhko, M.; Barbakov, O. Social Mood of Rural Residents in the South of Tyumen Region. Sociol. Stud. 2016, 3, 82-87.

63. Xing, C.; Zhang, J. The Preference for Larger Cities in China: Evidence from Rural-Urban Migrants. China Econ. Rev. 2017, 43, 72-90. [CrossRef]

64. Erokhin, V. Approaches to Sustainable Rural Development in a Predominantly Non-Rural Region. Econ. Agric. 2014, 2, 291-306. [CrossRef]

65. Ivolga, A. Overview of Contemporary Issues of Sustainable Rural Development in Russia in Terms of Existing Differences between Regions. Econ. Agric. 2014, 2, 331-345. [CrossRef]

66. Beloglazov, G. Food Security of China and its Russian Vector. Russia APR 2007, 3, 75-83.

67. Torre, A.; Wallet, F. Regional Development in Rural Areas. Analytical Tools and Public Policies; Springer: Cham, Switzerland, 2016.

68. Wang, X. Labor Market Behavior of Chinese Rural Households during Transition. Available online: https:/ / www.econstor.eu/bitstream/10419/45976/1/55723753X.pdf (accessed on 20 April 2018).

69. Chen, Z.; Ju, D.; Zhang, A. Measuring External Benefits of Agricultural Land Preservation: An Application of Choice Experiment in Wuhan, China. Acta Ecol. Sin. 2013, 33, 3213-3221. [CrossRef]

70. Yang, Y.; Meng, J. Environment Pollution State and Improvement Measures in Rural Areas of Heilongjiang, China. Nat. Environ. Pollut. Technol. 2017, 16, 1087-1093.

71. Lee, Y.C.; Ahern, J.; Yeh, C.T. Ecosystem Services in Peri-Urban Landscapes: The Effects of Agricultural Landscape Change on Ecosystem Services in Taiwan's Western Coastal Plain. Landsc. Urban Plan. 2015, 139, 137-148. [CrossRef]

72. Kroeger, T.; Casey, F. An Assessment of Market-Based Approaches to Providing Ecosystem Services on Agricultural Lands. Ecol. Econ. 2007, 64, 321-332. [CrossRef]

73. Liu, C.; Lu, J.; Yin, R. An Estimation of the Effects of China's Priority Forestry Programs on Farmers' Income. Environ. Manag. 2010, 45, 526-540. [CrossRef] [PubMed]

74. Feng, Z.; Yang, Y.; Zhang, Y.; Zhang, P.; Li, Y. Grain-for-Green Policy and its Impacts on Grain Supply in West China. Land Use Policy 2005, 22, 301-312. [CrossRef]

75. Uchida, E.; Xu, J.; Rozelle, S. Grain for Green: Cost-Effectiveness and Sustainability of China's Conservation Set-Aside Program. Land Econ. 2005, 81, 247-264. [CrossRef]

76. Song, M.; Huntsinger, L.; Han, M. How does the Ecological Well-Being of Urban and Rural Residents Change with Rural-Urban Land Conversion? The Case of Hubei, China. Sustainability 2018, 10, 527. [CrossRef]

77. Zhang, H.; Cheng, G. China's Food Security Strategy Reform: An Emerging Global Agricultural Policy. In China's Global Quest for Resources Energy, Food and Water; Wu, F., Zhang, H., Eds.; Routledge: London, UK, 2016; pp. 23-41.

78. Meng, L.; Zhao, M.N. Permanent and Temporary Rural-Urban Migration in China: Evidence from Field Surveys. China Econ. Rev. 2017. [CrossRef]

79. Gustafsson, B.A.; Ding, S. Temporary and Persistent Poverty among Ethnic Minorities and the Majority in Rural China. Rev. Income Wealth 2009, 55, 588-606. [CrossRef]

80. Gao, Y. Large Farms vs. Small Farms: Grain Production in Northwestern Shandong. Rural China 2014, 11, 222-243.

81. Stoian, D.; Donovan, J.; Fisk, J.; Muldoon, M. Value-Chain Development for Rural Poverty Reduction: A Reality Check and a Warning. In Innovation for Inclusive Value-Chain Development: Successes and Challenges; Devaux, A., Torero, M., Donovan, J., Horton, D., Eds.; IFPRI: Washington, DC, USA, 2016; pp. 75-92.

82. Chen, S.; Liu, Z. What Determines the Settlement Intention of Rural Migrants in China? Economic Incentives versus Sociocultural Conditions. Habitat Int. 2014, 58, 42-50. [CrossRef]

83. Zhang, K.; Song, S. Rural-Urban Migration and Urbanization in China: Evidence from Time-Series and Cross-Section Analyses. China Econ. Rev. 2003, 14, 386-400. [CrossRef]

84. Han, B. Move Odyssey in China: Rural-Urban Migration and Subsequent Relocation in Cities. Int. J. Migr. Resid. Mobil. 2014, 1, 12-27. [CrossRef] 
85. Chen, G.; Hamori, S. Rural Labor Migration, Discrimination, and the New Dual Labor Market in China; Springer: Cham, Switzerland, 2014.

86. Zhang, L.; Sharpe, R.V.; Li, S.; Darity, W.A. Wage Differentials between Urban and Rural-Urban Migrant Workers in China. China Econ. Rev. 2016, 41, 222-233. [CrossRef]

87. Izotov, D. Northeast China's Economy under the World Financial Crisis. Econ. Reg. 2010, 4, $229-233$. [CrossRef]

88. National Bureau of Statistics of China. Statistical Database. Available online: http://www.stats.gov.cn/ english/Statisticaldata / AnnualData / (accessed on 8 March 2018).

89. Bell, C. Combating Rural Poverty in China. Available online: http:/ /www.borgenmagazine.com/combatingrural-poverty-china/ (accessed on 7 March 2018).

90. Rozelle, S.; Taylor, J.E.; de Brauw, A. Migration, Remittances, and Productivity in China. Am. Econ. Rev. 1999, 89, 287-291. [CrossRef]

91. Li, L. Migration, Remittances, and Agricultural Productivity in Small Farming Systems in Northwest China. China Agric. Econ. Rev. 2013, 5, 5-23. [CrossRef]

92. Khuziyatov, T. Regional Economic Policy of China: The Strategy of North-Eastern Regions Revival. Reg. Econ. Sociol. 2005, 4, 200-207.

93. Tobin, D. Inequality in China: Rural Poverty Persists as Urban Wealth Balloons. Available online: http:/ / www.bbc.com/news/business-13945072 (accessed on 18 April 2018).

94. Knight, J.; Song, L.; Gunatilaka, R. Subjective Well-Being and Its Determinants in Rural China; University of Oxford: Oxford, UK, 2007.

(c) 2018 by the authors. Licensee MDPI, Basel, Switzerland. This article is an open access article distributed under the terms and conditions of the Creative Commons Attribution (CC BY) license (http:/ / creativecommons.org/licenses/by/4.0/). 